\title{
KANONSKOPRAVNI I POVIJESNI ASPEKTI KREACIJE NADBISKUPA ZAGREBAČKOG BL. ALOJZIJA STEPINCA KARDINALOM SVETE RIMSKE CRIVE Otkriće njegove naslovne crkve u Rimu
}

Veleposlanik Neven Pelicarić, mag. iur.*
UDK: 27-558.7(456.31)Stepinac, A. 235.3(456.31)Stepinac, A. DOI: 10.3935/zpfz.71.5.01 Izvorni znanstveni rad Primljeno: prosinac 2021.

Na osnovi dosad nepoznatog dokumenta pronađenog u vatikanskom arhivu Ureda za bogoslužna slavlja Vrhovnog svećenika, autor pronalazi da je tijekom konzistorija 12. siječnja 1953. papa Pio XII. (Pacelli) novoizabranom kardinalu Alojziju Stepincu dodijelio naslovnu crkvu te da je to bila Sancti Pauli in Arenula (San Paolo alla Regola). Razraden je postupak utvrdivanja istinitosti i vjerodostojnosti pronađenog dokumenta. Objašnjeni su i mogući razlozi zbog kojih se dosad pitanje postojanja i identifikacije Stepinčeve naslovne crkve nije istraživalo, unatoč dobro poznatoj činjenici da po kanonskom pravu svakom novoizabranom kardinalu mora biti dodijeljena naslovna crkva u Rimu. Opisane su i okolnosti u kojima se predmetni konzistorij odvijao te neposredne negativne posljedice po diplomatske odnose Svete Stolice i Federativne Narodne Republike Jugoslavije.

Ključne riječi: Alojzije Stepinac, kardinal, konzistorij, naslovna crkva

* Neven Pelicarić, mag. iur., savjetnik Predsjednika Republike za vanjsku i europsku politiku, Pantovčak 241, 10000 Zagreb; neven.pelicaric@predsjednik.hr;

ORCID ID: orcid.org/0000-0003-3032-5300 


\section{KARDINALI SVETE RIMSKE CRIKVE}

U upravljačko-savjetodavnoj strukturi Katoličke Crkve od samih njezinih početaka posebno mjesto zauzimaju kardinali (stožernici). ${ }^{1}$ Bitna su svojstva kardinalstva - uključujući nužna svojstva kandidata za kreiranje kardinalom, postupak imenovanja kardinala te kardinalska prava i dužnosti - opisana i propisana Zakonikom kanonskog prava, ovdje konzultiran u dvama izdanjima: CIC-1917. ${ }^{2}$, koji je bio na snazi u vrijeme kojim se ovaj članak bavi, te CIC-1983. ${ }^{3}$, koji je na snazi danas. Odredbe Zakonika kanonskog prava koje se odnose na kardinale Svete rimske Crkve sadržane su u Poglavlju III (kann. 230 do 24l) CIC-1917., odnosno u Knjizi II, Odsjeku I, Poglavlju III (kann. 349 do 359) CIC-1983.

Kardinali su "najviši suradnici i savjetnici pape u upravljanju sveopćom Crkvom". Iz tog je bliskog suradničkog položaja "odmah do pape" proizišlo i pogrešno, ali vrlo rasprostranjeno, shvaćanje da kardinalat pripada u stupnjeve (svećeničkog) ređenja, dakle da klerici hijerarhijski napreduju od đakonata, preko prezbiterijata i biskupstva do kardinalstva. No, naslov (titula) kardinala ima počasni karakter i ne pripada hijerarhiji stupnjeva ređenja, što posve jasno pokazuje i činjenica da je, doduše, češće u srednjovjekovlju nego u novije doba, Sveti Otac kardinalima kreirao i kandidate koji nisu bili svećenici. ${ }^{5}$

1 Etimologija riječi "kardinal” dolazi od latinske riječi cardo, čije se značenje "stožer, stožernik' razvilo od ranijeg ‘šarka velikih vrata, usađena u pod i nadvratnik oko koje se vrata okreću'. Naime, u vrijeme rimskih progona kršćana, dok se služba Božja održavala u nekoj prostoriji u tajnosti, osobe od povjerenja čuvale su vrata i u slučaju napada rimskih vojnika prve nastradale. Stoga i danas kardinali, kao simbol krvi, odijevaju prepoznatljivu crvenu, grimiznu boju.

2 Codex Iuris Canonici, Pii X Pontificis Maximi iussu digestus Benedicti Papae XV auctoritate promulgatus, u: AAS, vol. 9, II, 1917., str. 11 - 456; hrvatsko izdanje: Kodeks kanonskog prava, uređen po odredbi Svetog Oca Pape Pija X., proglašen po nalogu Pape Benedikta XV., preveo Franjo Herman, priredio Matija Berljak, Glas koncila, Zagreb, 2007. (dalje: CIC-1917.).

3 Codex Iuris Canonici, auctoritate Ioannis Pauli PP. II promulgatus, u: AAS, vol. 75, II, 1983., str. 1 - 317; hrvatsko izdanje: Zakonik kanonskog prava, proglašen vlašću Ivana Pavla II., s izvorima, Glas koncila, Zagreb, 1996. (dalje: CIC-1983.); usporedi službeni prijevod na mrežnoj stranici https://hbk.hr/wp-content/uploads/2018/11/Zakonik_kanonakoga_prava.pdf. Treba upozoriti na lapsus calami u sâmoj poveznici, koji rezultira pogreškom u pretrazi: umjesto "kanonskoga" piše "kanonakoga".

4 Enciclopedia 1949 = Enciclopedia cattolica, III (Bra - Col), Ente per l'Enciclopedia cattolica per il libro cattolico, Sansoni, Firenze, 1949.

5 U ranijim stoljećima nije bilo neuobičajeno da se kardinalom imenuje "laik". Ta praksa se polako tijekom XVII. i XVIII. stoljeća izobičajila, da bi do kraja XIX. sto- 
Moglo bi se, međutim, reći kako kardinali čine vrh hijerarhijskog ustroja upravljanja Crkvom. Oni su (u pravilu) na čelu najviših kurijalnih institucija Svete Stolice: kongregacija, dikasterija, tajništva i papinskih vijeća - dakle: svojevrsnog upravnog tijela opće Crkve. S druge strane, oni kolektivno konstituiraju Sveti kolegij, partikularno tijelo koje se uobičajeno naziva Kardinalskim zborom, na koji pada obveza izbora novog rimskog prvosvećenika nakon što se uprazni Katedra sv. Petra $\left(\right.$ konklava $\left.^{6}\right)$. Konačno: kako kolektivno, tako i individualno, papu savjetuju o najvažnijim pitanjima uprave Crkve, već prema područjima koja im papa prethodno povjeri i za što ih zaduži. ${ }^{7}$

Rimski prvosvećenik kardinale kreira $^{8}$ nakon što ih slobodno izabere među muškarcima (muževima) koji imaju barem svećenički red. ${ }^{9}$ Papa za kardinale

ljeća u potpunosti nestala. Međutim, tek je kodifikacijom kanonskog prava 1917. godine (CIC-1917., kan. 232, § 1.) papa Benedikt XV. (della Chiesa) propisao da je za kardinala nužan barem svećenički red.

Ovdje valja pojasniti kako su se tijekom povijesti klerici dijelili na one koji su primili "niže" redove i one koji su primili "više" redove. Niži redovi, u uzlaznom slijedu, bili su vratar, čitač, egzorcist, akolit, a pod nazivom viši ili sveti redovi bili su podđakon, đakon, prezbiter. Važno je reći da su klerici nižih redova i u Crkvi zapadnog (latinskog) obreda bili oslobođeni obveze celibata te su mogli valjano sklopiti brak, ali samo ako je brak bio sklopljen prije primanja svetog reda, i to isključivo s djevicom (sic!). (Usporedi Boudinhon, Auguste, Minor Orders, u: The Catholic Encyclopedia, vol. 10, Robert Appleton Company, New York, 1911. (12. veljače 2021.). Dostupno na: http://www.newadvent.org/cathen/10332b.htm.

Uobičajen - iako pogrešan - naziv “kardinali laici” proistječe upravo iz činjenice da su mogli biti oženjeni, iako su zapravo pripadnici kleričkog, a ne laičkog staleža.

6 Konklavom se naziva serija sjednica kardinala s ciljem izbora novog biskupa Rima i novog Vrhovnog svećenika. Izbor se odvija uzastopnim tajnim glasovanjem kardinala elektora (onih koji na dan upražnjenja Katedre sv. Petra nisu navršili 80 godina) zatvorenih (zaključanih cum clave [pod ključem] - stoga "konklava”) u Sikstinskoj kapeli, po četiri puta dnevno, sve dok se ne postigne dvotrećinska većina. O povijesnom razvoju instituta konklave, osobito i o kuriozitetima, vidi Bešker, Inoslav, Iza vatikanskih zidina, EPH, Zagreb, 2013.

7 CIC-1983., kan. 349.

8 Kardinali se ne "rede" jer nije riječ o stupnju u svećeničkom ređenju (kojih ima samo tri: đakonat, prezbiterat i episkopat, nazvan još i "punina svećeništva”); kardinali se ne "imenuju", niti se "promoviraju". Kardinali se "kreiraju", što je terminus technicus koji se odnosi samo na postupak u kojem (nad)biskupi te (u iznimnim slučajevima i svećenici) na posebnom svečanom slavlju koje predvodi Papa postaju kardinali.

Valja dodati da hrvatski službeni prijevod CIC-a ne poznaje termin "kreirati", već ga mijenja izrazom "imenovati”, o čemu dalje u tekstu.

9 Posljednji "laik" koji je primio samo niži red (tzv. tonzuru) bio je kardinal Tedolfo Mertel, poznati pravnik, odvjetnik i visoki dužnosnik tadašnje Papinske Države, 
bira one "... koji imaju barem red prezbiterata /.../ te se odlikuju naukom, ćudoređem, pobožnošću i razboritošću u radu, /.../ oni koji još nisu biskupi moraju primiti biskupsko posvećenje". ${ }^{10}$

Koliko se god tijekom povijesti mijenjala uloga, značenje i broj kardinala ${ }^{11}$, u njihovu položaju i službi postoje i određene konstante. Osim dobro poznatog prava i dužnosti da u konklavi biraju papu, novoizabrani kardinali obvezuju se prisegnuti na vjernost papi, ispovjediti vjeru i zavjetovati se da će ostati vjerni Crkvi "sve do prolijevanja krvi” (lat. usque ad sanguinis effusione), što se na simboličnoj razini izražava kleričkim odijelom posebne purpurne, grimizno crvene boje.

kojeg je papa bl. Pio IX. (Mastai-Ferretti) 1858. godine uključio u Kardinalski zbor. Tijekom svoje dugogodišnje kardinalske službe čak je postao kardinal protođakon, pa je na njega pala obaveza objaviti pûku izbor pape Lava XIII. (Peccija) nakon konklave 1878. godine te ga - zbog spriječenosti kamerlenga - čak i okruniti na krunidbenoj misi kojom je svečano uveden u službu Petrova nasljednika. On je bio zadnji kardinal koji nije imao svećenički red te nije mogao služiti misu. Usporedi Pierantozzi, Gaudenzio, Teodolfo Mertel - L'ultimo Cardinale laico, Edizioni Cantagalli, Siena, 2016.

10 Usporedi CIC-1983., kan. 351, § 1.

Zanimljivo je da i u današnjem Kardinalskom zboru postoje kardinali koji nisu zaređeni za biskupe, nego su prilikom kreiranja kardinalima ostali svećenici, pribavivši prethodno posebno Papino dopuštenje - dispenzu - od biskupskog ređenja: kardinal Albert Vanhoye (kreiran 24. ožujka 2006.), kardinal Ernst Simeoni (kreiran 19. studenoga 2016.) te kardinal Rainero Cantalamessa (kreiran 28. studenoga 2020.).

11 Kardinala je do kraja srednjeg vijeka bilo uglavnom oko 15, da bi se u XV. stoljeću njihov broj povećao na oko 70. Stoga je Papa hrvatskog porijekla Siksto V. (Peretti) odlučio apostolskom konstitucijom Post quam verus ille od 3. prosinca 1586. godine (usporedi Bullarum diplomatum et privilegiorum Sanctorum Romanorum Pontificum Taurinenses editio, 25 vols., Seb. Franco et Henrico Dalmazzo editoribus, vol. 8, LXXVI, 1857. - 1872., Turin, str. 808 - 816.) ograničiti njihov broj na najviše 70, temeljeno na broju od 70 staraca koje je Mojsije odredio kao vođe Židova kao izabranog naroda. Odredbe pape Siksta V. potvrđene su kanonom 231 CIC-1917., što je promijenio tek papa Ivan XXIII. (Roncalli) uzimajući u obzir povećane potrebe rastuće Crkve, osobito izvan Europe, te je njihov broj de facto povećao na 90. Pravu reformu Kardinalskog zbora čini tek papa Pavao VI. (Montini) apostolskom konstitucijom Romano Pontifici eligendo od 1. listopada 1975. (usporedi http://www.vatican.va/content/paul-vi/it/apost_constitutions/documents/hf_p-vi_apc_19751001 romano-pontifici-eligendo.html (5. prosinca 2020.)), kojom je kardinale po dobi podijelio na izbornike i neizbornike: odredio je da samo kardinali mlađi od 80 godina na dan upražnjenja Katedre sv. Petra mogu ući u konklavu, a njihov broj ograničio je na 120, iako su i on i kasniji pape - a osobito aktualni papa Franjo (Bergoglio) - često znali novim imenovanjima prekršiti taj numerus clausus. Kardinali stariji od 80 godina ne ulaze u taj broj. 


\section{POSTUPAK KREIRANJA KARDINALA}

U procesu postanka kardinalom govori se o raznim terminima kao što su: (a) najava, (b) imenovanje, (c) kreiranje, (d) proglašavanje i konačno (e) inkardinacija. Ovom prilikom moramo pojasniti svaki od tih termina.

Sveti Otac u nekom prigodnom trenutku, obično nakon redovitog Angelusa ili nakon Opće audijencije srijedom na Trgu sv. Petra, najavi (annuntio) da je odlučio sazvati "izvanredni konzistorij"12 na kojem će kreirati nove kardinale te tada pročita njihova imena, dakle imenuje (nominatio) one koji će postati kardinalima (usporedi CIC-1983., kan. 353, §§ 2-3.). Oni su uobičajeno bili unaprijed i u povjerenju upoznati s time da će ih papa uvrstiti u Kardinalski zbor, ali je tu praksu papa Franjo promijenio pa često bude riječ o velikom iznenađenju - neke od njih koji žive u drugim vremenskim zonama prijatelji bude u gluho doba noći da bi im čestitali.

Na sâmom konzistoriju papa kardinale kreira (creatio) i zatim pred Kardinalskim zborom (Sacrum Collegium - Sveti kolegij) svečano proglašava (enuntiatio) njihova imena. Od tog trenutka kardinali stječu sva prava i obveze koje iz tog statusa proistječu. Nakon toga slijedi inkardinacija (incardinatio) u kler grada Rima, koja se ostvaruje dodjeljivanjem naslovne crkve u Rimu. (usporedi CIC-1983., kan. 351, § 2.) ${ }^{13}$

12 Izvanredni konzistorij je skup cijelog Svetog kolegija odnosno Kardinalskog zbora, dakle svih kardinala koji mogu doputovati u Rim; od toga valja razlikovati redoviti konzistorij, kojemu prisustvuju kardinali rezidentni u Rimu i eventualno pojedini kardinali izvan Rima koje papa izrijekom pozove.

13 Željeli bismo istaknuti kako je CIC-1983. (https://www.vatican.va/archive/cod-iuris-canonici/latin/documents/cic_liberII_la.html) izrijekom definiran kao službeni tekst samo na svojem latinskom izvorniku. Službeni hrvatski prijevod objavila je Hrvatska biskupska konferencija (vidi supra bilj. 3), https://hbk.hr/wp-content/uploads/2018/11/Zakonik_kanonakoga_prava.pdf, te se ondje u prijevodu latinske riječi creatio (kan. 35l) upotrebljava hrvatski izraz "imenovati”, čime neobično odstupa od službenih prijevoda na autoru poznatim jezicima -

talijanskom: https://www.vatican.va/archive/cod-iuris-canonici/cic_index_it.html engleskom: https://www.vatican.va/archive/cod-iuris-canonici/cic_index_en.html španjolskom: https://www.vatican.va/archive/cod-iuris-canonici/cic_index_sp.html njemačkom: https://www.vatican.va/archive/cod-iuris-canonici/cic_index_ge.html francuskom: https://www.vatican.va/archive/cod-iuris-canonici/cic_index_fr.html portugalskom: https://www.vatican.va/archive/cod-iuris-canonici/portuguese/codexiuris-canonici_po.pdf.

Svi navedeni prijevodi naime upotrebljavaju analogni izraz "kreacija" kao terminus technicus. Naše je mišljenje da upotreba riječi “imenovati” u hrvatskom prijevodu u ovom kontekstu dovodi do određene pravne i terminološke nepreciznosti koja bi se 


\section{INKARDINACIJA KAO BITNO SVOJSTVO KARDINALATA}

Od svih je svojstava kardinalstva ovdje primarni predmet zanimanja inkardinacija, tj. upis novoimenovanog kardinala u kler Rimske biskupije. Taj je korak kanonski propisana i nužna sastavnica kreacije kardinala, a podrazumijeva da papa novokreiranom kardinalu dodijeli naslovno (titularno) đakonstvo ili naslovnu (titularnu) crkvu na području grada Rima (sve u okviru kardinalskoga zbora). ${ }^{14}$

Glavna funkcija kardinala Svete rimske Crkve, i jedina izrijekom pridržana samo i isključivo kardinalima, jest biranje novog rimskog prvosvećenika. Naime, u zapadnom (latinskom) kršćanstvu sve biskupe u pravilu imenuje Sv. Otac ${ }^{15}$, dok se jedino biskup Rima bira.

Prema tisućljetnoj tradiciji Kardinalski zbor dijeli se unutar sebe na redove, pa tako postoje kardinali đakoni, kardinali prezbiteri te kardinali biskupi. ${ }^{16} \mathrm{Ta}$ nikad prekinuta tradicija potječe još od vremena kad se rimski biskup birao po načelima antičkog Rima, gdje ga je birao rimski kler: rimski đakoni, svećenici (prezbiteri rimskih župa) i biskupi Rimu sufraganskih (prigradskih) biskupija. Papa Nikola II. (Gerard od Borgonje) na Rimskoj sinodi godine 1059. dekretom In Nomine Domini odredio je da apsolutnu prednost u izboru nasljednika sv. Petra imaju kardinali, a papa Aleksandar III. (Bandinelli) je najprije propisao dvotrećinsku većinu kao nužnu za pravovaljani izbor novog pape, da bi na Trećem lateranskom koncilu godine 1179. konstitucijom Licet de Evitanda izrijekom iz kruga osoba s pravom glasa pri izboru pape na konklavi isključio sve one koji nisu kardinali. ${ }^{17}$ Međutim, da bi se zadržao privid kako izbor rimskog biskupa

mogla izbjeći korištenjem navedenog kanonskog termina. U starijoj literaturi na hrvatskom jeziku za latinski izraz creatio u kontekstu kanonskog prava upotrebljavao se i termin "stvoriti”, što je (možda neopravdano) zabačeno u novije vrijeme.

14 Vidi CIC-1983., kan. 350, § 2.

15 I ovdje, kako je već uobičajeno u Katoličkoj Crkvi, postoje pojedine, iako rijetke, iznimke, a ovise o konkordatima s pojedinim državama i tzv. davnašnjim privilegijama.

16 Ovdje valja razlikovati pojam "red” u kontekstu svećeništva, odnosno svetog reda, koji jednom valjano primljen ostavlja trajni biljeg na ređeniku (opetujmo: red đakonata, red prezbiterata i red episkopata), od pojma "red" u kontekstu podjele Kardinalskog zbora (CIC-1983., kan. 350, § 1.).

17 I ovdje je važno napomenuti kako kanonsko pravo ograničava samo aktivno biračko pravo na isključivo kardinale okupljene u konklavi: nitko tko nije kardinal nema pravo glasa u konklavi. Nasuprot tome, kardinali nisu ograničeni da za papu izaberu nekoga izvan njihova kruga: dakle kanonsko pravo formalnopravno ne ograničava pasivno biračko pravo. Za rimskog prvosvećenika mogao bi tako - teorijski - biti izabran i samo svećenik koji odmah po izboru mora biti zaređen za biskupa (us- 
i dalje čini rimski kler, novim kardinalima papa mora dodijeliti naslovnu crkvu u Rimu, sukladno kanonskom pravu: Kardinalima prezbiterskog $i$ dakonskog reda rimski prvosvećenik dodjeljuje svakomu njegov naslov ili đakonstvo $u$ Rimu. ${ }^{18}$ Riječ je o kogentnoj pravnoj normi. Upravo ta činjenica predstavlja inkardinaciju kardinala u rimski kler. ${ }^{19}$

Da bi kardinali, kao pojedinci i kao kolegijalno tijelo, mogli valjano obavljati funkciju izbora rimskoga biskupa, nužno je da budu identificirani kao kler rimske biskupije, čime se - stekavši barem na taj način prebivalište u Rimu - inkardiniraju (ustožeruju) u rimski kler i stječu pravo ulaska u konklavu i biranja novog pape. ${ }^{20}$ Štoviše, obaveza je svakog novokreiranog kardinala da osobno uđe u posjed svoje naslovne crkve, ali to ne predstavlja konstitutivan čimbenik njegova kardinalskog statusa.

\section{KONSTITUTIVAN ČIN KREACIJE KARDINALOM}

Zbog razgraničenja, dakle, pojedinih pojmova iz postupka kreiranja kardinala potrebno je jasno definirati u kojem od navedenih ključnih trenutaka izabranik doista postaje kardinalom. U tom kontekstu valja naglasiti da je - u

poredi kan. 332 § 1. Rimski prvosvećenik potpunu i vrhovnu vlast u Crkvi dobiva osobnim prihvaćanjem zakonitog izbora zajedno s biskupskim posvećenjem. Zato onaj tko ima biskupski biljeg dobiva tu vlast od časa prihvaćanja izbora za vrhovno svećeništvo. Ako pak izabrani nema biskupskog biljega, neka se odmah zaredi za biskupa). Valja, međutim, reći kako se izbor kandidata koji nije bio kardinal zadnji puta dogodio 8. travnja 1378. godine, kad su kardinali u konklavi posegnuli izvan njihova kruga i izabrali nadbiskupa Barija Bartolomea Prignana, koji je okrunjen 10 dana poslije i zatim kao papa Urban VI. vladao 11 godina, a da prije izbora za rimskog prvosvećenika nije postao kardinalom.

Za izbor pape koji u trenutku izbora ne bi bio ni biskup - nema jasnih podataka $\mathrm{u}$ daljoj povijesti.

CIC-1983., kan. 350, § 2.

Jedini kardinali kojima se ne dodjeljuje rimska crkva kao naslovna jesu patrijarsi istočnih crkava kad ih papa promakne u kardinale, koji zadržavaju svoju rezidencijalnu patrijarhalnu arhieparhiju - ali oni se ex officio odmah pribrajaju u red kardinala biskupa i ne ubrajaju se u citirani kanonski propis.

20 Vidi Apostolsku konstituciju Universi Dominici Gregis 1996., str. 1, paragraf 6; Ioannes Paulus PP. II, Constitutione Apostolica Universi Dominici Gregis de Sede Apostolica vacante deque Romani Pontificis electione (22. II. 1996.), u: AAS, vol. 88, 1996. str. 305 - 343; neslužbeni prijevod na hrvatski jezik: Ivan Pavao II., Universi Dominici Gregis - Čitava Gospodnjega stada. O vremenu dok je Apostolska Stolica prazna, u: Balta, Petar (ur.), Konklave, Verbum, Split, 2005. 
skladu s propisanim obredom za kreiranje kardinala ${ }^{21}$ - intrinzičan i nužan, u punom smislu definirajući i - po mišljenju ovog autora - istinski konstituirajući kanonski element za postajanje kardinalom trenutak kada tijekom konzistorija ${ }^{22}$ okupljenih kardinala rimski prvosvećenik izgovori liturgijsku formulu kreiranja kardinala zajedno s imenom novouvrštenoga u Kardinalski zbor: Itaque auctoritate omnipotentis Dei, sanctorum Apostolorum Petri et Pauli ac Nostra, hos Venerabiles Fratres creamus et sollemniter enuntiamus Sancta Romana Ecclesia Cardinales....23; u hrvatskom prijevodu: "Vlašću svemogućeg Boga, svetih apostola Petra i Pavla, i našom, ovu časnu braću kreiramo i svečano proglašavamo kardinalima Svete rimske Crkve...".

Upravo ovaj tekst nam s apsolutnom preciznošću definira trenutak kada osoba tijekom konzistorija, te sasvim specifične svečanosti kreiranja, postaje kardinalom.

Naime, pape su biskupi (kako smo rekli, prva papinska služba je biskup Rima) i u obraćanju svojoj subraći u episkopatu koriste sintagmu Venerabiles Fratres (časna braća). Ipak, kako bi se dodatna čast ukazala kardinalima, što je i papa bio prije izbora u konklavi, njima se obraća sintagmom Venerabiles Fratres Nostros (naša časna braća). Činjenica da u formuli kreacije papa izgovara samo Venerabiles Fratres znači da im se obraća kao (još uvijek samo) biskupima, te da oni upravo u tom - kanonskopravno konstitutivnom činu - postaju kardinalima tek nakon što u nastavku iste rečenice čuju izrečeno vlastito ime. ${ }^{24}$

Tim činom osobe koje je papa najavio kao buduće kardinale stječu sva prava, obveze i povlastice koje proistječu iz njihova novoga statusa.

21 "Consistoro", Ufficio delle celebrazioni liturgiche del Sommo Pontefice, Consistoro Ordinario Pubblico per la creazione di nuovi Cardinali, l'imposizione della beretta, la consegna dell'anello, e l'assegnazione del Titolo o della Diaconia, Tipografia Vaticana, Citta del Vaticano, 2020.

22 Konzistorij je skup kardinala okupljenih oko pape radi rješavanja važnih pitanja, odnosno radi kreiranja novih kardinala (usporedi https://www.treccani.it/vocabolario/concistoro/).

23 Consistoro 2020., str. 9.

24 Valja ovdje istaknuti kako predmetne formulacije nisu nigdje formalno propisane te da naša ekstenzivna potraga za pronalaskom kodifikacije navedenog postupanja nije urodila plodom; nasuprot tome, izravni razgovori s nadležnima koji i provode ovakvu praksu (konzultirani ravnatelji papinskih bogoslužnih slavlja te šef Odjela za latinski jezik u Prvoj sekciji Državnog tajništva Svete Stolice, nadležnog za svu službenu papinsku korespondenciju na latinskom) upućuju na stillum Curiae, dakle ustaljenu i uvriježenu praksu koja se konzistentno može slijediti unatrag najmanje do vremena pape sv. Pija V. (Ghisilerija), velikog reformatora Rimske kurije (1566. 1572.) te kao takva predstavlja valjani znanstveni izvor. Stoljetna je dakle praksa u Kuriji da se papa formulacijom Venerabiles Fratres obraća biskupima, a formulacijom Venerabiles Fratres Nostros samo i isključivo kardinalima. 


\section{PREDMET ISTRAŽIVANJA: KARDINALAT, INKARDINACIJA I PRIPADAJUĆA RIMSKA NASLOVNA CRIKVA KARDINALA ALOJZIJA STEPINCA}

Do sada, tj. tijekom života blaženog kardinala Stepinca, njegova čašćenja (nakon preminuća) kao časnog sluge Božjega te procesa beatifikacije i još uvijek aktivnog procesa kanonizacije, nije u javnosti izneseno koja je bila njegova naslovna crkva u Rimu. Taj se podatak ne nalazi ni na jednom popisu ili kojem drugom javno dostupnom dokumentu niti se pitanje Stepinčeve rimske naslovne crkve ne otvara ili propituje u (ovom autoru) poznatim biografijama i drugim knjigama o Stepincu. ${ }^{25}$

Mogući razlozi izostanka spomena Stepinčeve naslovne crkve u javnosti ovdje nisu predmet istraživanja niti se podrobnije razmatra u osnovi začudna činjenica da se Stepinčevi biografi i stručnjaci koji su radili na njegovim kauzama i životopisima nisu uopće doticali te bjelodane aberacije njegove kreacije kardinalom, koja im je morala upasti u oči.

Tijekom ovoga istraživanja autor se više puta i u različitim prilikama konzultirao s pojedincima iz visokih crkvenih i akademskih institucija u vezi s pitanjem kako je Alojzije Stepinac valjano kreiran kardinalom, a da nije poznato koja mu je rimska naslovna crkva. Mišljenja i stavovi tih se pojedinaca mogu svrstati u dvije skupine.

U prvoj su pojedini stručnjaci koji, poput onih koji su, primjerice, povezani s Kongregacijom za biskupe i Državnim tajništvom Svete Stolice, dobro poznaju pravne propise i uzuse vezane uz kreiranje kardinala, ali istodobno nisu podrobno upoznati sa životopisom kardinala Stepinca. Među njima se moglo čuti mišljenje da je Stepinac možda imenovan in pectore ${ }^{26}$ (ali ne i za života proglašen)

25 Podatak o Stepinčevoj naslovnoj crkvi se ne nalazi (ni) u sljedećim izdanjima: Benigar, o. Aleksa, Alojzije Stepinac, hrvatski kardinal, II. popravljeno i prošireno izdanje, Glas Koncila i Hrvatska franjevačka provincija sv. Ćirila i Metoda, Zagreb, 1993.; Gavranović, Zvonimir, In Search of Cardinal Stepinac - A Complete Biography, Kršćanska sadašnjost, Zagreb, 2014.; Batelja, Juraj, Komunistički progon i mučeništvo blaženoga Alojzija Stepinca, Postulatura blaženoga Alojzija Stepinca, Zagreb, 2017.; Batelja, Juraj, Blaženi Alojzije Stepinac - svjedok Evanđelja ljubavi, Knjiga I: Životopis, Postulatura blaženoga Alojzija Stepinca, Zagreb, 2010.; Vraneković, Josip, Dnevnik - Život u Krašiću zasužnjenog nadbiskupa i kardinala Alojzija Stepinca (5. XII. 1951. - 10. II. 1960.), Postulatura blaženoga Alojzija Stepinca, Zagreb, 2011.

26 Kardinali in pectore su oni koje papa na temelju CIC-1917., kan. 233, § 2. (danas CIC-1983., kan. 351, § 3.) prilikom izgovaranja formule kreacije spomene samo u tišini, dakle "u svom srcu", ali im imena javno ne objavi. U pravilu riječ je o visokim prelatima za koje se smatra da bi im objava njihova imena mogla osobno naštetiti, 
s obrazloženjem da je nedostatak podatka o identifikaciji njegove rimske naslovne crkve formalnopravno nespojiv s valjanom kreacijom (za njegova života proglašenog) kardinala.

U drugoj su pak skupini pojedinci iz visokih crkvenih i akademskih krugova, hrvatski stručnjaci za ekleziološka i teološka pitanja (ali ne nužno i pitanja kanonskog prava) koji su, kako je očekivano, dobro upoznati sa životopisom blaženog kardinala. Među njima se obično čula neka inačica stava kako Stepincu rimska naslovna crkva nije nikada bila dodijeljena i to stoga što je - budući da je bio lišen slobode - bio onemogućen doći u Rim i ući u posjed takve crkve, sve da mu je i bila dodijeljena. Uz to se još, kao potpora stavu da Stepincu nije nikada dodijeljena rimska naslovna crkva, moglo čuti da bi podatak o identifikaciji Stepinčeve rimske naslovne crkve, nakon toliko godina detaljnog istraživanja Stepinčeva života, jamačno bio poznat - kad bi takva crkva postojala.

Nema sumnje da je kreiranje Alojzija Stepinca bilo pravovaljano jer je papa za njega izrekao propisano formulu tijekom konzistorija. On se stoga kao kardinal navodi u svim onodobnim relevantnim dokumentima te nema sumnje da je Stepinac bio i ostao kardinal. Tu činjenicu ni u čemu ne umanjuje to što: zbog svojeg utamničenja nikada nije dospio u Rim; nije pred papom ispovjedio vjeru ni prisegnuo na vjernost njemu i njegovim nasljednicima; iz papine ruke nije mogao preuzeti kardinalski biret ${ }^{27}$, kardinalski prsten i bulu kreiranja; te nikada nije ušao u posjed svoje kardinalske naslovne crkve - što su sve obveze novokreiranih kardinala.

Mislimo, dapače, kako je iznimno važno u tom kontekstu konstatirati da je papa Pio XII. upravo želio javno najaviti te zatim i proglasiti da je bl. Alojzija Stepinca (kao i kard. Stefana Wysynskog) kreirao, uvrstivši ih obojicu u red kardinala prezbitera, iako su u tom trenutku bili izloženi snažnom progonu komunističkih vlasti u tadašnjoj NR Poljskoj i FNR Jugoslaviji, dapače bili su i osuđeni na dugogodišnje kazne zatvora i utamničeni, a da nije izabrao kreaciju in pectore. Tu činjenicu procjenjujemo važnim diplomatskim potezom koji oslikava tadašnje stanje odnosa Svete Stolice i komunističkih diktatura istočne Europe.

koji se nalaze u zemljama gdje je Crkva progonjena. Česti su bili takvi slučajevi u zemljama koje su u dano vrijeme bile diktature. Papa u nekom kasnijem trenutku može objaviti ime tako kreiranog kardinala i on tada javno zauzima svoje mjesto u Kardinalskom zboru sukladno preseansu konzistorija na kojem je kreiran, ali nije objavljen. Postoje brojni slučajevi da se nikada nije doznalo ime tako kreiranih kardinala jer je papa koji ih je kreirao umro a da nije otkrio njihova imena.

27 Biret je četverokutna klerička kapa s tri "krila” na vrhu, koja se razlikuje u bojama: svećenički biret je crne boje; monsinjorski, biskupski i nadbiskupski bireti su ljubičaste boje; dok je kardinalski grimizne boje. 
S obzirom na dvije nespojive okolnosti - s jedne strane, da se ništa ne zna o mogućoj Stepinčevoj rimskoj naslovnoj crkvi, a s druge strane, da je dodjela rimske naslovne crkve nužna sastavnica kreiranja kardinalom - kao predmet su ovoga istraživanja definirana dva posebna i jedno općenito pitanje.

Prvo pitanje: Je li papa Pio XII. (Pacelli) pri kreiranju nadbiskupa zagrebačkoga Alojzija Stepinca kardinalom, što je nedvojbeno učinio tijekom konzistorija 12. siječnja 1953. godine, novom kardinalu dodijelio rimsku naslovnu crkvu?

Drugo pitanje: S obzirom na to da je Alojziju Stepincu kanonskopravno morala biti dodijeljena kardinalska naslovna crkva u Rimu, koja je to točno crkva bila?

Treće pitanje: Koji je konstitutivan trenutak valjanje kreacije kardinalom, te ovisi li kardinalski status o ulasku u posjed naslovne crkve?

\section{NEPOSTOJANJE IZVORA O NASLOVNOJ CRKVI KARDINALA STEPINCA U RIMU}

U uobičajenim javno dostupnim izvorima za podatak o naslovnoj crkvi novokreiranih kardinala - poput službenog godišnjaka Annuario Pontificio, službenoga glasila Svete Stolice Acta Apostolica Sedis i vatikanskoga dnevnog lista L'Osservatore Romano - nema takvog podatka za kardinala Stepinca. ${ }^{28}$ Sustavnija pretraga na internetu dostupnog arhivskog gradiva ${ }^{29}$ utvrdila je da su u više od 500 posljednjih godina iznimno rijetki slučajevi kardinalskog kreiranja bez

28 Na dan konzistorija, 12. siječnja 1953. godine, tijekom kojega su kreirana 24 kardinala, L'Osservatore Romano spominje sva njihova imena. U sljedećim brojevima isti dnevni list objavljuje naslovne crkve dodijeljene pojedinima od novoizabranih kardinala, no ne i za Alojzija Stepinca. Acta Apostolica Sedis za 1953. godinu objavljuju službenu informaciju da je Stepinac kreiran kardinalom, ali samo spominju da ga je papa uvrstio u red kardinala prezbitera, ne imenujući - kako je uobičajeno - njegovu naslovnu crkvu u Rimu. Godišnjak Annuario Pontificio u razdoblju od 1953. do 1960. konzistentno navodi Stepinca među kardinalima, kao kardinala prezbitera, ali na mjestu naslovne crkve samo stoje tri točke (“..”), što je jedini takav slučaj, uz napomenu da je spriječen.

29 Mrežna stranica www.catholic-hierarchy.org na poveznici http://www.catholic-hierarchy.org/event/consist.html (20. studenoga 2020.) sadržava podrobne podatke o svim konzistorijima unatrag do 1456. godine i fragmentarne podatke za ranije konzistorije. Od 1456. godine do danas održana su ukupno 464 konzistorija: 27 u XV. stoljeću, 92 u XVI., 69 u XVII., 103 u XVIII., 108 u XIX., 51 u XX. te 14 (do sada) u XXI. stoljeću. Fragmentarno zabilježenih ranijih konzistorija bilo je 159: 1 u VI. stoljeću, 10 u VII., 13 u VIII., 13 u IX., 14 u X., 15 u XI., 23 u XII., 20 u XIII., 30 u XIV. te 20 u XV. stoljeću (do 1449. godine). 
istodobnog određivanja naslovne crkve, i to uvijek zbog neke posve izvanredne okolnosti. ${ }^{30}$

Odluka pape Franje obznanjena na audijenciji čelništvu i suradnicima Tajnog vatikanskog arhiva 4. ožujka 2019. godine ${ }^{31}$ da će 2. ožujka 2020. - na osamdesetprvu obljetnicu izbora pape Pija XII. na Petrovu stolicu (ali i 144. obljetnicu njegova rođenja $)^{32}$ - otvoriti arhivsko gradivo iz vremena njegova pontifikata

30 Tako je, kao primjer vremenski najbliži Stepinčevoj kreaciji, onaj s konzistorija 11. prosinca 1905. godine kada je kardinalom kreiran nadbiskup Seville bl. Marcelo Spinola y Maestre, također bez objave naslovne crkve, vjerujemo stoga što je novoizabrani kardinal umro neposredno nakon kreiranja i dodijeljenu mu naslovnu crkvu nije stigao preuzeti. Daljnje istraživanje u povijesnom arhivu Nadbiskupije u Sevilli pokazalo je da ni oni, doista, nemaju podatak o njegovoj naslovnoj crkvi, ali je ostao zapis da je nadbiskup svoj kardinalski solideo (malenu kapicu jednostavna konveksnog oblika) primio iz ruku papinskog legata nekoliko dana nakon konzistorija, dok mu je kardinalski biret (u skladu s davnašnjom privilegijom apostolskog veličanstva) na glavu 31. prosinca 1905. u Madridu stavio španjolski kralj Alfonso XIII. Bl. Marcelo već 19. siječnja 1906. umire u Sevilli, tako nije stigao doputovati u Rim i iz ruku pape Pija X. (Sarta) primiti kardinalski naslov. Naša pretraga arhive Ureda za bogoslužna slavlja Vrhovnog svećenika potvrdila je da za konzistorij 1905. godine nije sačuvan popis naslovnih kardinalskih crkava.

Osim toga, više je primjera da je osoba koju je papa već najavio i imenovao za kardinala umrla u razdoblju između najave održavanja konzistorija na kojem se ta osoba imala kreirati kardinalom i samog datuma održavanja tog konzistorija. U takvim slučajevima osoba nije ni mogla postati kardinalom niti joj je mogla biti dodijeljena rimska naslovna crkva, no u biografsku se notu te osobe stavlja važna naznaka "uzdignut na kardinalsku čast - umro prije kreiranja". Tako je Stepinčevu primjeru najbliži relativno nedavan slučaj hrvatskoga nadbiskupa, mons. Josipa Uhača, dugogodišnjeg nuncija i tajnika Kongregacije za evangelizaciju naroda. Njega je papa sv. Ivan Pavao II. uvrstio u popis novoizabranih kardinala u najavi za konzistorij koji se imao održati 21. veljače 1998. (što je Uhaču službeno dojavljeno tri dana ranije), ali je on (s nepune 74 godine) umro u jutro samog dana najave toga konzistorija. (vidi sv. Ivan Pavao II., Angelus, 18. siječnja 1998., prema priopćenju Državnog tajništva Svete Stolice, dostupno na: http://www.vatican.va/content/john-paul-ii/en/ angelus/1998/documents/hf_jp-ii_ang_18011998.html (7. prosinca 2020.)).

31 Vidi priopćenje Tiskovnog ureda Svete Stolice od 4. ožujka 2019., dostupno na: https://press.vatican.va/content/salastampa/it/bollettino/pubblico/2019/03/04/0185/ 00375.html (7. prosinca 2020.).

32 Kao i svaka druga država, tako i Sveta Stolica ima svoja specifična pravila o čuvanju i pristupu arhivskoj građi. Dok je u svijetu uobičajeno da se pojedinim dokumentima omogućuje pristup 25, 30 ili 50 godina nakon njihova nastanka, Vatikan ima praksu da se javnosti čine dostupnima dokumenti koji se odnose na pojedini pontifikat u cjelini, i to u pravilu tek 70 godina nakon smrti pape o kojemu je riječ. To se čini kako bi se u prvom redu osiguralo da su praktički sve osobe koje 
za znanstveno istraživanje, pružila nam je nove mogućnosti traženja odgovora na pitanje je li kardinalu Stepincu dodijeljena koja rimska crkva kao naslovna te, ako jest - koja je to bila.

Pretraživanja arhiva i drugih mjesta za koja se moglo pretpostaviti da bi mogla pružiti odgovore na postavljena pitanja, pa ni uz pristup dokumentaciji Pija XII. iz vremena prije i neposredno nakon predmetnog konzistorija održanoga 1953. godine, nisu dala rezultata. Pretražili smo tako arhivsku građu Kongregacije za nauk vjere ${ }^{33}$, Kongregacije za kauze svetih ${ }^{34}$, Kongregacije za biskupe ${ }^{35}$, tajništva Kardinalskoga zbora $^{36}$, za što se pokazalo ili da nema podataka, ili da arhivska građa nije relevantna za naše istraživanje. Zatim smo pregledali Apostolski arhiv te arhiv Prve sekcije za opće poslove i Druge sekcije za odnose s državama Državnoga tajništva. U ovom potonjem pronađena su oveća dva registratora koja su se odnosila na potrebu da se u Nadbiskupiji zagrebačkoj imenuje nasljednik već bolesnom i ostarjelom nadbiskupu Antunu Baueru u

se u dokumentima spominju već umrle. Također, tako se može očuvati integritet arhivske građe.

Prema tom principu arhivska građa nastala u pontifikatu Pija XII. - dakle od 1939. do 1958. godine - bila bi dostupna tek 2028. godine. Papa Franjo je, međutim, zbog iznimnog javnog i znanstvenog interesa za aktivnosti Pija XII., osobito tijekom i neposredno nakon II. svjetskog rata, taj rok skratio, i odlučio da će građa istraživačima biti dostupna od 2020. godine.

Također, građa se relevantna za ovo istraživanje ne čuva samo u Apostolskom arhivu (donedavno poznatom kao Vatikanskom tajnom arhivu), iako je on najveći i najpoznatiji. U sklopu raznih dikasterija Svete Stolice postoje zasebni arhivi - njih više od 10 - koji čuvaju građu, a nekima od njih smo tijekom ovog istraživanja imali priliku pristupiti.

33 Arhiva Kongregacije za nauk vjere (Archivum Sacræ Congregationis pro Doctrina Fidei: ACDF, S.O., Rerum Variarum (R.V.) 1941., 7 (Prot. 230/1941): Zagabria. Con la formazione del nuovo stato di Croazia molti fedeli che prima apostatarono dalla fede cattolica perché forzati dal governo scismatico, ora vorrebbero ritornare alla Madre Chiesa ecc.; ACDF, S.O., Rerum Variarum (R.V.) 1946, 51 (Prot. 417/1946): Zagabria. Circa il processo contro l'Arcivescovo ed $i$ suoi accusatori.

Congregatio de Causis Sanctorum, Pos. P.N. 1762., Positio super Martyrio Servi Dei Aloysii Stepinac, Vol. I. - IV., Roma, 1996. (arhivska signatura: I. 74a/2).

Za biskupska imenovanja na teritoriju tadašnje Kraljevine Jugoslavije bila je nadležna tadašnja Sveta kongregacija za izvanredne crkvene poslove - Sacra Congregazione degli Affari Ecclesiastici Straordinari, AA.EE.SS. (današnja Sekcija za odnose s državama u Državnom tajništvu Svete Stolice), tako da u Kongregaciji za biskupe nema relevantne dokumentacije. 
obliku nadbiskupa koadjutora cum iure succesionis ${ }^{37}$, dok je nama relevantan dio arhiva Sekcije za opće poslove već djelomično bio prebačen u Apostolski arhiv na trajno čuvanje. ${ }^{38}$ Dokumenti dostupni u navedenim arhivima su, očekivano, potvrđivali činjenicu da je Alojzije Stepinac imenovan prvo zagrebačkim nadbiskupom koadjutorom, gdje je naslijedio umrlog nadbiskupa Bauera, te da je 1953. kreiran kardinalom i uvršten u Kardinalski zbor, ali ni u jednom nije nađen spomen moguće njegove naslovne crkve. ${ }^{39}$

\section{PRONALAZAK IZVORNOG DOKUMENTA}

Navedeni razlozi zatim su nas usmjerili na pretraživanje sada dostupne arhive i spisâ koji su se odnosili upravo na konzistorij održan 1953. godine. U malo poznatom arhivu Ureda za bogoslužna slavlja Vrhovnog svećenika ${ }^{40}$, koji se bavi među ostalim i pripremom konzistorija, u sklopu jedne vrlo prašnjave zbirke

37 Dokumenti na temu potrage za nasljednikom nadbiskupa Bauera u Arhivu Državnog tajništva (vidi AA.EE.SS, Pio XI, IV. periodo, Jugoslavia, Pos. 97, P.O, Fasc. 68-69) vrlo jasno govore o teškom stanju Nadbiskupije zagrebačke u tom trenutku (tadašnji nuncij u Beogradu nadbiskup Ermengildo Pelegrinetti ga naziva "žalosnim”). Iz tih se dokumenata, a njihov ukupan sadržaj zavrjeđuje zaseban znanstveni članak, doznaje da se nadbiskupov nasljednik intenzivno tražio pune četiri godine (1930. - 1934.). Tijekom toga su razdoblja brojne osobe uzete u obzir kao mogući više ili manje pogodni nasljednici nadbiskupske službe, a za najmanje osmoricu kandidata bio je i pokrenut formalni postupak ispitivanja podobnosti za episkopat. Za dvojicu kandidata citirani arhivski spis sadržava čak i naputak kardinala državnog tajnika Eugenija Pacellija nunciju Pelegrinettiju da ih je papa Pio XI. imenovao za nadbiskupe koadjutore - pa se imenovanja zbog različitih razloga nisu ostvarila. To se sve događalo prije nego što se došlo do Stepinčeva imena, koji se pojavljuje kao osmi kandidat.

Jednom kad se postupak pokrenuo o njemu, bio je dovršen u rekordnom vremenu. Od prvog spominjanja njegova imena do njegova imenovanja prošlo je jedva mjesec dana.

38 Kako nas je na naše traženje dopisom izvijestio arhivar Prve sekcije za opće poslove Državnog tajništva mons. Assunto Scotti (dokument o tome u osobnoj arhivi autora).

39 U Apostolskom arhivu pronađen je dokument izvorno izrađen u Prvoj sekciji DrŽavnog tajništva, tzv. minuta - pisaćim strojem pisana kopija teksta koja je odaslana kaligrafima da rukopisno ispišu Stepinčevu bulu imenovanja - u kojoj, sukladno očekivanom, nije bilo referencije na naslovnu crkvu u Rimu (vidi Apostolski arhiv, Cancelleria Apostolica, Regesta Litterarum Apostolicarum 85, fasc. 41). "Minuta" je protekom vremena trajno arhivirana u Apostolskom arhivu.

40 Officium de Liturgicis Celebrationibus Summi Pontificis; tal. Ufficio delle celebrazioni liturgiche del Sommo Pontefice. 
dokumenata vezane uz Pija XII., a odnosili su se na pripreme za konzistorij održan 1953. godine, pronađen je nama relevantan dokument: na papiru formata A3 presavijenom u dvolist formata A4, pisan strojem, s u zaglavlju upisanom tadašnjom Prefekturom apostolskih ceremonija, bez datacije i potpisa, naslovljen Assegnazione dei titoli ai nuovi Eminentissimi, tj. »Dodjela naslova novim uzoritim «. ${ }^{41}$

Riječ je o dokumentu koji je zapravo radni podsjetnik za djelatnike Ureda za bogoslužna slavlja, kakvi se uobičajeno sastavljaju dan ili dva prije održavanja konzistorija na kojem se kreiraju kardinali.

$\mathrm{Na}$ prvoj se stranici toga dvolista nalazi popis 15 novih kardinala (među njima i Stepinca), sa svakomu od njih dodijeljenom naslovnom crkvom. $\mathrm{Na}$ drugoj je stranici popisano preostalih devet novih kardinala, također sa svojim naslovnim crkvama. Na trećoj je stranici tekst naslovljen Nota dei ceremonieri che assistono i nuovi Eminentissimi, tj. »Uputa monsinjorima ceremonijarima koji prate nove Uzorite «2 ${ }^{42}$, na kojem je samo 18 imena onih kardinala koji su dojavili da će doputovati u Rim. Četvrta stranica dokumenta je prazna.

Među petnaestoricom kardinala s prve stranice navedenoga dvolista u jedanaestom retku nalazi se ime Alojzija Stepinca (naveden na talijanskom, kao Luigi Stepinac). No za razliku od svih ostalih do sada poznatih dokumenata o kreiranju Alojzija Stepinca kardinalom, ovaj dokument sadržava i podatak o njegovoj naslovnoj crkvi - riječ je o crkvi Sancti Pauli in Arenula ${ }^{43}$, poznatija kao San Paolo alla Regola. ${ }^{44}$

${ }^{41}$ Archivio dell'Ufficio delle Celebrazioni Liturgiche del Sommo Pontefice (dalje u tekstu: ACP), ACP 0246, Concistori 1946-1954, istruzioni per una canonizzazione, fasc. 5 - preslika u privitku.

42 Naime, uobičajena je praksa da papinski ceremonijar, poznat kao ravnatelj papinskih bogoslužnih slavlja, nakon najave održavanja konzistorija i kreiranja novih kardinala pripremi listu prijedloga za naslovne crkve s liste slobodnih, koje nisu u tom trenutku "zauzete" živućim kardinalima. U Rimu postoji 279 naslovnih crkava i đakonata, a kardinala je trenutno 214. Uvijek, dakle, postoji "rezerva” za nova imenovanja, ponajprije stoga što se pojedine crkve tradicionalno “čuvaju” za kardinale iz pojedinih zemalja.

43 Kao naslovna crkva u rangu đakonata ta crkva je ustanovljena apostolskom konstitucijom Pija XII. Sancti Hadriani Ecclesia od 25. siječnja 1946., kojom je tisućljetni đakonat sv. Hadrijana na Forumu (Sancti Hadriani in Foro, San'Adriano al Foro), ustanovljena još 630. godine od pape Honorija I., ukinuta, i njezin naslov prenesen na Sancti Pauli in Arenula. (vidi https://it.wikipedia.org/wiki/San_Paolo_alla_Regola_(diaconia) (22. veljače 2021.)).

44 Naziv Sancti Pauli in Arenula je ojkonim: ime predstavlja vezu s povijesnim rimskim rioneom, dakle naseljenom četvrti antičkog Rima pod imenom Arenula; kasnije je u srednjovjekovnom talijanskom taj naziv iskvaren u Reola, pa Revola i konačno 


\section{POSTUPAK PROVJERE VJERODOSTOJNOSTI IZVORNOG DOKUMENTA}

Iz prethodno spomenute činjenice da dokument koji pored imena Alojzija Stepinca navodi njegovu naslovnu crkvu nije datiran i nema potpisa, proizlazi nužnost postavljanja pitanja o vjerodostojnosti toga dokumenta: je li riječ o radnom prijedlogu, o nacrtu, ili pak o istinskoj volji pape Pija XII.?

U tom je pogledu ključan upravo sadržaj treće stranice toga dvolista, tj. upute monsinjorima ceremonijarima koji su određeni biti u pratnji pojedinih kardinala kako bi im pomogli pri pokleku pred papom i primanju kardinalskoga bireta, prstena i bule iz papinih ruku.

Prema riječima aktualnog ravnatelja papinskih bogoslužnih slavlja mons. Guida Marinija, i njegova prethodnika na toj službi, nadbiskupa mons. Piera Marinija, upravo činjenica da predmetni dvolist sadržava naputak za papinske ceremonijare jamči da je riječ o popisu koji je Sveti Otac već odobrio. Nema naime nikakve mogućnosti da bi tekst podsjetnika za uključene u ceremoniju kreiranja kardinala bio sastavljen i za što drugo osim za konačan - tj. od pape odobren - popis novoizabranih kardinala i njihovih naslova. ${ }^{45}$

Nenadana se dodatna potvrda da je doista riječ o vjerodostojnom dokumentu za identifikaciju Stepinčeve naslovne crkve također nalazi na toj trećoj stranici pronađenoga dvolista. Na njoj naime nisu navedena imena onih kardinala ${ }^{46} \mathrm{za}$ koje se znalo da neće moći sudjelovati u konzistoriju. Tako se na toj stranici ne

Regola te je četvrt konačno postala alla Regola; naziv potječe od latinskog arena pijesak - jer je zbog blizine rijeke Tibera prije izgradnje nasipa često plavila i ostavljala naslage pijeska (vidi Parisi, Giovanni, La prima dimora di San Paolo a Roma, Casa Editrice Carteggio, Torino, 1959., str. 175 - 180).

45 Kao i brojne druge stvari vezane za Katoličku Crkvu, i ovaj opisani postupak u cijelosti je rezultat stoljetne tradicije koja nigdje nije kodificirana. Tako ne postoji zakonski ili proceduralni tekst kojim bi se definirala ili razradila ova procedura jer se to "oduvijek tako radilo". Tim uskim segmentom djelovanja Ureda za bogoslužna slavlja i ravnatelja papinskih bogoslužnih slavlja nije se nitko prema našim spoznajama do sada bavio te nismo našli odgovarajuće literature s tim u svezi. (usporedi Magistri Coeremoniarum na vatikanskim mrežnim stranicama http://www.vatican.va/ news_services/liturgy/2006/documents/ns_lit_doc_20061031_magistri-caeremoniarum_it.html (17. veljače 2021.)). I opet, riječ je o stillum Curiax.

46 Od dvadeset četvorice na tom konzistoriju kreiranih kardinala nije Stepinac bio jedini koji je izostao s ceremonije. Nunciji iz Lisabona, Madrida i Pariza - Pietro Ciriaci, Gaetano Cicognani i Angelo Giuseppe Roncalli, te dvojica španjolskih nadbiskupa Tarragone i Santiaga de Compostele - Benjamin de Arriba y Castro i Fernando Quiroga y Palacios, najavljeno nisu došli u Rim na konzistorij. Ime kardinala Wyszyńskog uneseno je na trećoj stranici, ali je prekriženo. 
nalaze imena trojice nuncija i dvojice španjolskih nadbiskupa koji su kreirani kardinalima, a za koje se unaprijed znalo da neće moći doći na konzistorij svoje kreacije. Oni su doputovali u Rim krajem listopada 1953. godine te su na skupnoj ceremoniji 29. listopada 1953. iz papinih ruku preuzeli bule sa svojim naslovnim crkvama. ${ }^{47}$

Očekivano, među onima čije ime nije navedeno na trećoj stranici predmetnog dvolista je i Alojzije Stepinac, tada konfiniran u Krašiću, o čemu također postoji dokument. ${ }^{48}$ Drukčije je sa Stefanom Wyszyńskim, nadbiskupom Gniezna i primasom Poljske. Njegovo je ime navedeno na trećoj stranici dvolista, očito stoga što je do zadnjeg časa postojala nada da će uspjeti doputovati iz Poljske na konzistorij svog kreiranja kardinalom. No, njegovo je ime i rukom prekriženo, vjerojatno tek na dan održavanja konzistorija kad je postalo posve jasno da ipak neće stići, i to zbog dobro poznatih dramatičnih okolnosti u tadašnjoj Poljskoj (a tako i Hrvatskoj i drugim zemljama komunističke političke orijentacije). I baš taj potez olovkom, vjerojatno baš rukom tadašnjeg ravnatelja papinskih bogoslužnih slavlja mons. Enrica Dantea ${ }^{49}$, kojim je prekriženo ime poljskog primasa, dodatno nam pomaže ustanoviti i dokazati vjerodostojnost dokumenta.

47 Kao zanimljivost navodimo da oni nisu čekali listopad kako bi kardinalski biret preuzeli iz papinih ruku: španjolskim kardinalima i nunciju u Madridu biret je na glavu stavio tadašnji španjolski šef države, caudillo Francisco Franco, nunciju u Lisabonu portugalski predsjednik Francisco Craveiro Lopez, a budući papa Ivan XXIII. Roncalli biret je dobio od francuskog predsjednika Vincenta Auriola.

48 Archivio dell'Ufficio delle Celebrazioni Liturgiche del Sommo Pontefice - ACP, vol. 889, Diario di A. Fattinnanzi 1953., fasc. 60, ACP 0234, carte varie sui concistori 19501953, fasc. 5.

49 Mons. Enrico Dante imenovan je ravnateljem papinskih bogoslužnih slavlja 1947. godine u zreloj životnoj dobi od 63 godine, nakon što je na Papinskom sveučilištu Gregoriana stekao doktorate iz filozofije, teologije i "obaju prava" (utriusque iuris) te je kasnije postao i odvjetnikom na Rimskoj roti, sudu Apostolske stolice. Nakon što je predavao na Papinskom sveučilištu Urbaniana - sve vrijeme radeći i kao jedan od papinskih ceremonijara - imenovan je prefektom i tim je Uredom upravljao gotovo 20 godina, pri čemu je poduzeo brojne reforme. Organizirao je izvanredni konzistorij 25. siječnja 1959. na kojem je papa Ivan XXIII. Roncalli najavio sazivanje II. vatikanskog koncila te je kasnije na sva četiri zasjedanja sudjelovao kao koncilski otac. Godine 1960. imenovan je za tajnika današnje Kongregacije za kauze svetih, 1962. zaređen je za naslovnog nadbiskupa Carpasije, ali je do 1965. nastavio ravnati Uredom za bogoslužna slavlja. Nije se slagao s reformama koje je Koncil planirao uvesti te je 1965. godine, na istom konzistoriju kao i Stepinčev nasljednik na katedri zagrebačkih nadbiskupa Franjo Šeper, kreiran kardinalom naslovnikom Sant'Agata de'Goti i umirovljen jer je već bio stariji od 80 godina. Sudjelovao je kao liturgičar na konklavama 1914., 1922., 1939., 1958. te 1963., kao i na krunidbi Benedikta XV., Pija XI., Pija XII., Ivana XXIII. i Pavla VI. 
Naime, kardinal Wyszyński u Rim je stigao tek četiri i pol godine kasnije, 1957. godine, nakon što je pušten iz zatočeništva u Poljskoj. On je 10. svibnja 1957., posredstvom kardinala Giuseppea Pizzarda, tadašnjeg prefekta Kongregacije za sjemeništa i sveučilišta, te mons. Angela Dell'Acque, tadašnjeg zamjenika (Sostituta) državnog tajnika uputio Sv. Ocu posebnu i osobnu molbu, da mu se umjesto za njega predviđene crkve Santi Quirico e Giulitta dodijeli crkva Santa Maria in Trastevere. ${ }^{50} \mathrm{U}$ dopisu je Wyszyński naveo kako je potonjoj crkvi raniji naslovljenik bio, te je u njoj i pokopan, poljski kardinal Stanisław Hosius (1504. - 1579.), iz vremena Tridentinskog koncila, prvi nuncij pri caru Svetog Rimskog Carstva i kasnije veliki pokorničar Svete rimske Crkve. Također, ta crkva prva je u Rimu bila posvećena Majci Božjoj, koju je Wyszyński posebno pobožno štovao te je imao Mariju u svojem kardinalskom grbu. Molbu je Pio XII. odmah prihvatio: tako je kard. Wyszyński već 18. svibnja 1957. pred Svetim Ocem položio propisanu kardinalsku zakletvu i ušao u posjed svoje naslovne crkve. ${ }^{51}$

Drugim riječima, iz navedenog je slijeda jasno da je još početkom svibnja 1957. godine, kada je kard. Wyszyński stigao u Rim, vrijedila papina odluka upisana na nama ključnom popisu kardinalskih naslovnih crkava iz 1953. godine, a prema kojoj je kard. Wyszyńskom dodijeljena crkva Santi Quirico e Giulitta, zbog čega je on aktivno poduzeo korake da se ta odluka preinači, u čemu je i uspio.

Svi preostali kardinali preuzeli su upravo onu crkvu koja je njihovu imenu pridružena u tom dokumentu.

Zbog svega navedenoga može se zaključiti da je novopronađeni dvolist vjerodostojan dokument o tomu da je zagrebačkom nadbiskupu Alojziju Stepincu bila dodijeljena kardinalska naslovna crkva u Rimu, da je to bila upravo crkva San Paolo alla Regola te da bi, da je ikada nakon svoje kreacije kardinalom mogao doći u Rim, on i osobno ušao u posjed.

\section{POVIJESNI ZNAČAJ CRKVE SAN PAOLO ALLA REGOLA}

U današnjem je svojem obliku crkva San Paolo alla Regola sagrađena 1740. godine u baroknom stilu, s mnogo mramornih ukrasa, u kojoj se desno od glavnog oltara nalazi zasebna mala kapelica Divi Pavli Apostoli Hospitvm et Schola, poznata i kao Schola Sancti Pauli, puno skromnijeg, gotovo asketskog uređenja. Crkva se nalazi u povijesnom centru Rima i vrlo je važna u rimskoj povijesti i povijesti Katoličke Crkve. Kapelica simbolički predstavlja mjesto na kojem je apostol sv. Pavao podučavao i pisao, a tijekom arheoloških istraživanja

50 ACP 0258, Atti e funzioni varie, 1953-1957, fascicolo VIII., Atti 1957, № 7.

51 ACP 0258, Atti e funzioni varie, 1953-1957, fascicolo VIII., Atti 1957, № 9. 
provedenih sredinom XX. stoljeća utvrđeno je više povijesnih slojeva koji se nalaze ispod temelja današnje crkve.

Po tradiciji i pobožnoj predaji ${ }^{52}$ upravo je na tom mjestu stajala kuća u kojoj je godinama bio konfiniran apostol Pavao nakon što je iz Jeruzalema došao u Rim 60. ili pak 61. godine. ${ }^{53}$ Razlog je njegova dovođenja dobro poznat: Pavao je tražio da se kazneni postupak koji se protiv njega imao pokrenuti u Jeruzalemu vodi u gradu Rimu, što je povlastica koju mu je pripadala na osnovi činjenice da je, iako po narodnosti Židov, imao status rimskog građanina (lat. civis Romanus). Na mjestu svoje konfinacije, svojevrsnog kućnog pritvora, sv. Pavao smio se ograničeno kretati i, što je možda još važnije, raditi, pa je u tom kontekstu važno primijetiti dvije činjenice. Jedna je da se to mjesto nalazi u neposrednoj blizini negdašnjeg židovskog Geta, a druga da se za cara Augusta i kasnije odvijala živa komercijalna djelatnost u skladištima i obrtničkim radionicama smještenima u tom dijelu Rima. Prva mu je činjenica omogućavala aktivno i vrlo intenzivno djelovanje naviještanja Evanđelja među rimskim Židovima, a druga da u blizini tadašnje luke na rijeci Tiberu zarađuje za život šivanjem kožnih nadstrešnica za dućane za prodaju robe koju su iz rimske morske luke u Ostiji prevozili u Grad, u čemu je, prema zapisima, kao obrtnik kožar sv. Pavao bio vješt.

U svakom slučaju, nastavlja predaja, Pavao je tijekom razdoblja svojeg rimskog kućnog pritvora intenzivno naučavao vjeru, pa i napisao neke svoje poslanice (Kološanima, Filemonu, Efežanima i Filipljanima), što su sve dodatni razlozi zbog kojih je već u IV. stoljeću, ubrzo nakon Milanskog edikta ${ }^{54}$, tu sagrađena malena crkva $^{55}$ koja je dostojno komemorirala mjesto Pavlova rimskog boravišta. Štoviše, u toj je prvosagrađenoj crkvi navodno bila sačuvana i ćelija u kojoj je boravio apostol Pavao. Na istom je mjestu u XIII. stoljeću sagrađena druga crkva ${ }^{56}$, da bi je zatim kao ruševnu u XVIII. stoljeću zamijenila postojeća, barokna crkva.

52 Sveto pismo i tradicija predstavljaju izvor katoličke vjere (Katekizam Katoličke crkve, §75-100).

53 Putem je Pavao preživio brodolom koji se - prema prihvaćenoj povjesnici - dogodio na Malti, iako neki naši povjesničari iznose da se on možda dogodio kod Mljeta.

54 Milanski edikt, Hrvatska enciklopedija, mrežno izdanje, Leksikografski zavod "Miroslav Krleža”, 2020., dostupno na: http://www.enciklopedija.hr/Natuknica.aspx?ID= 40820 (16. prosinca 2020.).

55 Pretpostavka je da se na tom mjestu nalazilo svetište kao oratorium ili možda ecclesia domestica, koja bi u vrijeme pape sv. Silvestra I. (314. - 335.) ili možda iz vremena pape sv. Damasa I. (366. - 384.) bila preuređena u jednobrodnu crkvicu, tako malenu da su je deminutivno nazivali San Paolino. (vidi Parisi, p. Giovanni T.O.R., San Paolo alla Regola, Editrice Anaclecta, Rim, 2009., str. 33 - 34).

56 Ostao je zapis vizitacije te crkve iz 1566. godine u kojem stoji da je crkva "vlažna i tamna te loše popločana” te da čuva relikvije iz vremena pape Urbana II. (Eudesa 


\section{SIMBOLIKA KARDINALSKE NASLOVNE CRIKVE DODIJELJENE ALOJZIJU STEPINCU}

Ovdje se u tom kontekstu valja prisjetiti homilije koju je Pio XII. održao na konzistoriju 12. siječnja 1953. obraćajući se novokreiranim kardinalima, iz koje je jasno vidljiva razina njegova poštovanja prema položaju u kojem se nalazi bez vlastite krivnje i nepokolebljivom stavu koji je u toj situaciji zauzeo zagrebački nadbiskup i upravo kreirani kardinal Stepinac. Stavljajući u povijesni kontekst, valja reći da se konzistorij događa nekoliko tjedana nakon što je FNRJ prekinula diplomatske odnose sa Svetom Stolicom i "zamolila" otpravnika poslova i diplomatsko osoblje da napusti Beograd. Sveti Otac je naime čak više od trećine svoje homilije posvetio upravo njemu ${ }^{57}$, što ovdje donosimo u hrvatskom prijevodu:

Premda se radujemo, časna braćo, što vas vidimo ovdje pred Nama, mislimo sa žalošću na našega časnoga brata, zagrebačkog nadbiskupa, kojemu zbog okolnosti u kojima se nalazi nije bilo dano da dođe u Rim $k$ zajedničkom ocu i da se slobodno vrati. Iako je odsutan, Mi ga očinskom ljubavlju grlimo i živo želimo da bi cio svijet znao da smo ga počastili dostojanstvom rimskog grimiza, ali ni iz jednoga drugog razloga nego samo da nagradimo njegove izvanredne zasluge, kao i da posvjedočimo njegovu narodu Našu dobrohotnost, da na osobit način pohvalimo i utješimo Naše drage sinove i kćeri koji u tim teškim vremenima ispovijedaju odlučno svoju katoličku vjeru.

Nipošto se ne podudara s istinom da smo ubrajanjem ovoga prelata u Sveti kolegij htjeli izazvati i vrijeđati jugoslavenske vlasti. Niti je ovaj Naš izbor odgovor na prežestoke riječi kojima Nas i Apostolsku Stolicu ocrnjuju. Prežestoke riječi, opetujemo, koje opraštamo i zaboravljamo.

Savjest Naša nije mogla odobriti da priznamo i odobrimo razloge koje se u optužbi zagrebačkog nadbiskupa navode. A nismo mogli razočarati ni nadu i očekivanje katolika cijeloga svijeta, kao i dobrog broja nekatolika, koji su s velikim zadovoljstvom primili vijest da je pastir, koji je uzor apostolske gorliivosti i kršćanske jakosti, podignut na dostojanstvo Rimskog grimiza. Uza sve to što je kardinalat posve crkveno dostojanstvo, ipak državni poglavari i njihovi narodi običavaju očitovati najveću radost kad je tko od njihovih sugradana pozvan da bude član vašeg Svetog Zbora.

de Lagerya); usporedi Armellini, Mariano, Le chiese di Roma dal secolo IV al XIX, Tipografia Vaticana, Roma, 1891., str. 398; citirano prema: https://penelope.uchicago.edu/Thayer/I/Gazetteer/Places/Europe/Italy/Lazio/Roma/Rome/churches/_Texts/ Armellini/ARMCHI*/2/Regola.html\#refl (11. prosinca 2020.).

57 Usporedi L'Osservatore Romano, A. XCIII., Num 9 (28.162), 12. - 13. siječnja 1953. str. 2. 
Svatko iole upoznat sa životom i ukupnom crkvenom karijerom Eugenija Pacellija, tj. pape Pija XII., zna da je riječ o dugogodišnjem izvrsnom diplomatu i zatim mudrom državniku. Iz gornjeg citata i vidimo da je bio vidno zabrinut događajima koji su se odvili u Jugoslaviji u razdoblju od najave konzistorija 29. studenoga 1952. do njegova održavanja 12. siječnja 1953. godine, tijekom kojeg je režim u Beogradu prekinuo diplomatske odnose sa Svetom Stolicom. Također, da mu je upravo nadbiskup zagrebački tih dana bjelodano bio intenzivno u mislima.

Uvjereni smo stoga da neuobičajeni izbor upravo kardinalske đakonije San Paolo alla Regola, a ne neke u tom trenutku slobodne naslovne crkve, za kardinala Stepinca nikako nije bio slučajan, nego je riječ o smišljenom činu kojim je papa poslao važnu poruku time što je crkvu podignutu na mjestu višegodišnje konfinacije progonjenog apostola Pavla dodijelio baš nadbiskupu zagrebačkom, proganjanom i konfiniranom u svojem rodnom mjestu. ${ }^{58}$

\section{IZOSTANAK JAVNOG SPOMENA DODIJELJENE NASLOVNE CRKVE I KONTEKST DIPLOMATSKIH ODNOSA SVETE STOLICE I FNRJ}

No, ako je papa Pio XII. doista tim izborom kardinalske naslovne Stepinčeve crkve javnosti želio poslati određenu poruku, postavlja se pitanje zašto identifikacijski podatak o toj crkvi nikad nije objavljen, nego je upravo suprotno - tako rubno zabilježen da je ostao do danas nepoznat. O tome se možda ne mogu donijeti konačni zaključci, ali se mogu iznijeti određene argumentirane pretpostavke.

58 Valja napomenuti da nije uobičajeno, iako nije ni sasvim nepoznato, da se kao naslovnik đakonije imenuje kardinal prezbiter. U tom slučaju, posebnim dekretom, predmetna đakonija se pro hac vice (za taj slučaj) privremeno podiže na rang naslovne prezbiterske crkve, a nakon smrti naslovnika crkva se vraća na rang naslovne đakonije. To bi se i propisalo u ovom slučaju u papinskoj buli da je Stepinac bio u mogućnosti preuzeti svoju naslovnu crkvu.

Ističemo, međutim, kako za ovakav postupak mora postojati neki osobit razlog. Stoga nam i činjenica da je Pio XII. odlučio jednu đakoniju privremeno uzdići na rang naslovne crkve govori da je postojala specifična namjera i svrha novokreiranom kardinalu Stepincu dodijeliti upravo ovu, a ne neku drugu naslovnu crkvu. A ta svrha - uvjereni smo - mora biti baš poveznica utamničenja sv. Pavla i kard. Stepinca. 
Jedna je od njih mogućnost da je namjera Svete Stolice bila da u tim teškim okolnostima ipak pokuša sačuvati diplomatske odnose s Beogradom, što smo željeli dublje istražiti.

Naime, poznata je činjenica da su diplomatski odnosi Svete Stolice i FNRJ i prije najave konzistorija koji se imao održati u siječnju 1953. godine bili vrlo napeti, kako zbog odnosa komunističkih vlasti prema Crkvi, progona i oduzimanja imovine, tako i zbog utamničenja nadbiskupa zagrebačkog i brojnih drugih svećenika.

Upravo je subota 29. studenoga 1952. godine određena za dan službene najave konzistorija koji se imao održati u siječnju 1953. godine. Slučajno ili ne, riječ je o datumu Dana Republike, nacionalnog praznika bivše Federativne Narodne Republike Jugoslavije, kada se u Beogradu održavao veliki diplomatski prijam u povodu nacionalnog dana. Već je ujutro toga dana u Beograd, u tamošnje sjedište Apostolske nuncijature, stigao kriptirani teleks $\mathrm{s}^{59}$ koji je potpisao upravo mons. Giovanni Battista Montini (budući papa Pavao VI.), inače baš tog dana imenovan prodržavnim tajnikom Svete Stolice ${ }^{60}$. Tekst koji glasi: "Radosno

59 Šifrirani je teleks zaveden pod brojem Ufficio Cifra (Ured za šifriranje) № 370 te adresiran i datiran "Nuncijatura Beograd, 29. XI. 1952.”. (Povijesni arhiv Državnog tajništva, današnje Sekcije za odnose s državama, a tadašnje Sekcije za izvanredne crkvene poslove; vidi Archivio Storico Segreteria di Stato, Affari Ecclesiastici Straordinari (dalje u tekstu: AA.EE.SS.): Pio XII, Parte II 1948-1958, Jugoslavia, pozicija 324, folio 474).

Valja ovdje napomenuti da je u komunikaciji svih diplomatskih postaja sa svojim centralama već stoljećima uobičajena uporaba kriptirane komunikacije. U današnje doba sve se obavlja elektronički i automatski te se praktički sva službena komunikacija odašilje šifriranim kanalom. U doba prije računala kriptiranje je podrazumijevalo vrijeme i ljudski rad: svaka kriptirana komunikacija morala se ručno kriptirati na izvoru, ručno emitirati kriptiranim kanalom te zatim na destinaciji ručno zaprimiti i onda dešifrirati, što je podrazumijevalo barem dvoje ako ne i četvero službenika koji su na tome radili, uz utrošak vremena i ljudskih resursa. Stoga su kriptirane samo vrlo kratke poruke, i to one koje su se smatrale posebno osjetljivima, žurnima i vrlo važnima.

Činjenica da je ovaj teleks odaslan kriptiranim kanalom podrazumijeva s jedne strane njegovu važnost, a s druge i njegovu žurnost: Državno tajništvo apsolutno je željelo da Nuncijatura u Beogradu odmah ujutro dobije tada još tajnu informaciju o Stepinčevu uzdizanju na rang kardinala, prije nego što je vijest - istoga dana navečer - javno objavljena.

60 Funkcija državnog tajnika Svete Stolice usporediva je s premijerskom funkcijom u drugim državama. Papa Pio XII. u razdoblju od 1944. godine pa do kraja svojeg pontifikata 1958. nije imenovao državne tajnike, već je tu službu pridržao za sebe, dok se dnevnim poslovima bavio protajnik. Mons. Montini punih je 15 godina, još od 1937. pa sve do 1952., bio zamjenik državnog tajnika (Sostituto), da bi upravo 
izvješćujem Vaše velečasno gospodstvo da će Sveti Otac uzdignuti na Sveti grimiz Njegovu Ekselenciju monsinjora Stepinca na tajnom konzistoriju 12. siječnja. Montini"61 žurno je dostavljen Silviju Angelu Piju Oddiju, tadašnjem otpravniku poslova Nuncijature u Beogradu, kasnijem dugogodišnjem nunciju, prefektu Kongregacije za kler i kardinalu đakonu Sant’Agatha de'Goti.

Istoga su dana navečer svjetske novinske agencije prenijele vijest da je papa Pio XII. odlučio na tajnom konzistoriju 12. siječnja 1953. godine tadašnjeg zagrebačkog nadbiskupa i krašićkog uznika mons. Alojzija Stepinca kreirati kardinalom i uvrstiti u Kardinalski zbor. Ta se vijest, oglašena javno, proširila diplomatskim, vladinim i crkvenim krugovima, tada već okupljenim na večernjoj proslavi nacionalnog dana FNRJ kao šumski požar, kako je to opisao mons. Silvio Oddi u javljanju vatikanskom Državnom tajništvu. On je naime u dva izvješća - odaslanim diplomatskom poštom 5. i 6. prosinca 1952. godine, na 14 gusto tipkanih stranica s mnogobrojnim prilozima (na još čak 66 stranica!) - Državnom tajništvu poslao podrobno izvješće o, kako i sam piše, "prvim reakcijama" u Beogradu i Jugoslaviji. ${ }^{62}$ Tadašnja se jugoslavenska vlast ozbiljno mobilizirala

29. studenog 1952. bio imenovan protajnikom te mu je citirana komunikacija o Stepincu njegova prvog radnog dana u novom uredu zasigurno bio jedan od prvih ako ne baš i prvi službeni akt.

61 Pregiomi comunicare Signoria Vostra Reverendissima che Santo Padre eleverà alla Sacra Porpora Sua Eccellenza Monsignor Stepinac nel Concistoro Segreto 12 Gennaio. Montini.

62 Zadržat ćemo se samo na nekim Oddijevim impresijama. On navodi da je na prijemu za Dan Republike, u subotu 29. studenog navečer u Palači Federacije, “imao dojam da je pažnja prisutnih diplomata "bila puno manje usredotočena na novu sjajnu odoru maršala i na njegovu zračeću novu suprugu Jovanku Broz Tito" jer su bili ometeni viješću koja se šaputala u svim uglovima dvorane: Stepinac - kardinal!!" (istaknuto u originalu, op. a.).

Za razumijevanje te reakcije potrebno je znati kako je to bila praktički prva prilika u kojoj se široj javnosti predstavila Jovanka Broz, koju je Tito oženio još 15. travnja 1952. u tajnoj ceremoniji u Šarengradu. Prema kasnijem pisanju londonskog tiska o dotičnom prijemu "Maršal je bio u blistavoj novoj bijeloj odori s odličjima i zlatnim insignijama činova, a njegova mlada supruga u satenskoj bordo haljini sa zlatnim brošem s dijamantima”. Logično je, dakle, da su se predsjednik i prva dama našli zapostavljeni te slijedom toga zasigurno i uvrijeđeni.

Oddi nastavlja kako ga je veleposlanik SAD-a "kurtoazno i sa znatiželjom" ispitivao o Stepincu, dok veleposlanici Francuske i osobito Ujedinjene Kraljevine "nisu mogli sakriti svoje protivljenje ovom imenovanju”. Oddi zaključuje da bi se te dvije zemlje “zadovoljile jedino ako bi nadbiskup zauvijek napustio Jugoslaviju”. Zamjenik ministra vanjskih poslova Aleš Bebler na sâmom je diplomatskom prijemu uzvikivao: "Ovo je još jedna provokacija Vatikana!”.

Ubrzo su, u prokušanoj komunističkoj maniri, počeli pristizati “spontani” prosvjedi kulturnih saveza, akademske zajednice, radnika u tvornicama i seljaka iz radnih 
oko odašiljanja hitrog, sveobuhvatnog i oštrog odgovora i prije održavanja najavljenog konzistorija. Naime, već 17. prosinca 1952. godine Jugoslavija prekida diplomatske odnose s Vatikanom, zatvara svoje veleposlanstvo pri Svetoj Stolici i traži od Vatikana da zatvori svoje diplomatsko predstavništvo te protjeruje otpravnika poslova i diplomatsko osoblje. ${ }^{63}$

Ipak, ekstenzivnim pregledom obilne diplomatske arhive iz tog razdoblja u vatikanskom Državnom tajništvu nije pronađena korespondencija ni neki drugi trag koji bi ukazivali na razmišljanje da bi Vatikan, u možebitnom nastojanju da primiri tako napetu situaciju između Vatikana i Beograda, odlučio ne objaviti koju je crkvu dodijelio kardinalu Stepincu.

Zato se vjerojatnom čini druga mogućnost, tj. da je uzrok neobjavljivanja Stepinčeve naslovne crkve zapravo slučajan splet okolnosti: najprije se (u vrijeme same kreacije) nije inzistiralo na objavi tog podatka, to više što Stepinac nije mogao doći u Rim na konzistorij. Zatim se ovaj ionako rubno zabilježen podatak zametnuo, a onda su i oni koji su u početku bez sumnje znali Stepinčevu naslovnu crkvu taj podatak zaboravili, da bi kroz desetljeća (i sve do danas) ta aporija trajno ostala izvan glavnog tijeka diskursa o Stepincu.

\section{ZABORAV PODATKA O NASLOVNOJ CRKVI}

Opisani slijed događaja - koji se već ionako razlikuje od uobičajene prakse koja se primjenjuje prigodom uvrštavanja novih članova u Sveti kardinalski zbor - ima i vrlo neobičan završetak.

Papa Pio XII. umire u listopadu 1958. godine, a na konklavi istog mjeseca izabran je papa Ivan XXIII. Roncalli, kreiran tijekom istog konzistorija tijekom kojega je kreiran i Stepinac. Novi je papa svoj prvi konzistorij zakazao praktički odmah, već 15. prosinca 1958. godine. Među 23 nova kardinala koji su na taj dan kreirani nalazio se i apostolski nuncij u Italiji, nadbiskup Giuseppe Fietta ${ }^{64}$,

zadruga. Oddi daje detaljan pregled brojnih negativnih reakcija, uključivo predsjednika JAZU-a iz Zagreba akademika Marka Kostrenčića, predsjednika SANU-a iz Beograda akademika Aleksandra Belića, autora knjige Magnum Crimen dr. Viktora Novaka te nekih svećenika i fratara koji su pripadali "Patriotskom udruženju svećenika". Odluku Sv. Oca smatraju "rukavicom bačenom u lice herkulovskih napora maršala Tita u osiguravanju demokracije i odvojenosti Crkve od države”. Novine javljaju o "revoltu građana Hrvatske" i slično (vidi AA.EE.SS. Pio XII., Parte II. 1948-1958, Jugoslavia, pozicija 324, folio 394-473).

63 Vraneković, op. cit. u bilj. 25, str. 131; Benigar, op. cit. u bilj. 25, str. 671.

64 Kardinal Fietta, iako se nalazio u Rimu, nije došao na konzistorij, već je kardinalski biret primio iz ruku tadašnjeg predsjednika Talijanske Republike Gronchija, pred 
koji je istog dana i umirovljen s mjesta nuncija jer je upravo navršio kanonsku dob od 75 godina.

Fiettina je kardinalska kreacija relevantna za predmet ovog istraživanja jer je dotadašnjem nunciju dodijeljena ista crkva San Paolo alla Regola. Taj se čin može okarakterizirati kao radikalno protivan kanonskim propisima jer je Stepinac u to doba živ, valjano kreiran i javno objavljen kardinal upravo s tom naslovnom crkvom.

Popis naslovnih crkava za taj konzistorij iz 1958. godine se sačuvao ${ }^{65} \mathrm{Iz}$ njega je vidljivo da su pojedinim kardinalima rukom mijenjane naslovne crkve (za jednog i dvaput!), ali među njima ne i za kardinala Fiettu.

U osobnom razgovoru suočeni s ovim podatkom, donedavni i bivši ravnatelji papinskih bogoslužnih slavlja, mons. Guido Marini i nadbiskup Piero Marini, kao i djelatnici Ureda za bogoslužna slavlja Vrhovnog svećenika, u nevjerici su mogli samo odmahivati glavama. Naime, u to je doba Uredom još uvijek ravnao "povijesni" ravnatelj papinskih bogoslužnih slavlja mons. Enrico Dante ${ }^{66}$, čovjek koji je do danas - više od 50 godina nakon svoje smrti - na glasu kako po sveobuhvatnoj reformi Ureda koji je proveo zahvaljujući nevjerojatnom radnom elanu, tako i po svojoj fanatičnoj preciznosti. Čini se - kažu sugovornici - da je mons. Dante jednostavno zaboravio crkvu San Paolo alla Regola izbrisati s popisa "slobodnih" naslovnih crkava i pridružiti je Stepinčevu imenu na popisu "zauzetih" naslovnih crkava. To bi - kako navode njegovi nasljednici u službi - mogla biti možda i jedina omaška u čitavom njegovu dugogodišnjem radu.

\section{ZAKLJUČAK}

U okviru jedne zbirke dokumenata Pija XII., koja se čuva u malo poznatom arhivu Ureda za bogoslužna slavlja Vrhovnog svećenika (Officium de Liturgicis Celebrationibus Summi Pontificis; tal. Ufficio delle celebrazioni liturgiche del Sommo Pontefice), a odnosi se na pripreme za konzistorij održan 1953. godine,

cijelim diplomatskim zborom, okupljenom na božićnom čestitanju u predsjedničkoj palači Quirinaleu. (vidi Discorsi e messaggi del Presidente della Repubblica Giovanni Gronchi, Roma, 2009., str. 380).

ACP 0270, № 9.

Enrico Dante je na tom mjestu više od 20 godina služio trojici papâ te je i sâm kao kasniji tajnik Kongregacije za svete obrede (današnje Kongregacije za kauze svetih) zaslužio kardinalski biret, i to kao kardinal đakon one iste Sant'Agatha de'Goti, gdje je bio izravni prethodnik bivšem otpravniku poslova u Beogradu i kasnijem kardinalu Oddiju. 
pronašli smo dokument formata A3 presavijenog u dvolist formata A4, bez datacije i potpisa. Tekst je identificiran kao radni podsjetnik za djelatnike Ureda za bogoslužna slavlja koji su imali biti uključeni u ceremoniju kreiranja kardinala tijekom konzistorija održanog 1953. godine. U zaglavlju je upisana Prefektura apostolskih ceremonija, a naslovljen je: Dodjela naslova novim Uzoritim. ${ }^{67}$

Na prvoj je stranici toga dvolista, unutar popisa novih kardinala, upisano i ime Alojzija Stepinca na talijanskom jeziku, kao Luigi Steipinac, zajedno s podatkom o njemu dodijeljenoj naslovnoj crkvi - riječ je o crkvi Sancti Pauli in Arenula, poznatoj i kao San Paolo alla Regola. To je jedini poznati zapis podatka o identifikaciji Stepinčeve naslovne crkve.

Vjerodostojnost je podatka potvrđena sâmom činjenicom da je upisan u dokument koji se sastavlja neposredno prije održavanja kardinalske kreacije i da se na njemu ne mogu pojaviti podaci koji nisu u skladu s voljom pape. Nadalje, vjerodostojnost je dokumenta verificirana: mjestom čuvanja dokumenta, općim svojstvima njegove strukture i pojedinostima poput rukom unesenih ispravaka $\mathrm{u}$ inače strojem upisan tekst, sve kako je pokazano $\mathrm{u}$ prethodno opisanom istraživanju i tumačenju otkrivenih činjenica.

Netom navedenim činjenicama i u prethodnim tekstom obrazloženim analizama pružena je argumentirana osnova da se odgovori na pitanja koja su postavljena kao predmet ovoga istraživanja.

Na prvo pitanje - je li papa Pio XII. Alojziju Stepincu dodijelio rimsku naslovnu crkvu tijekom njegova kreiranja kardinalom - može se odgovoriti potvrdno.

$\mathrm{Na}$ drugo pitanje - koja je točno crkva Stepinčeva rimska naslovna crkva odgovor je: Sancti Pauli in Arenula (San Paolo alla Regola).

Na treće pitanje - koji je konstitutivan trenutak kreacije kardinalom, te ovisi li kardinalski status o ulasku u posjed naslovne crkve - odgovor je: kad tijekom konzistorija u formuli kreacije papa izgovori ime novokreiranog kardinala, pri čemu na njegov status kasnije ne utječe nemogućnost ulaska u posjed dodijeljene mu naslovne crkve $\mathrm{u}$ Rimu.

Na osnovi prikupljenih podataka i njihova tumačenja može se nešto reći i o mogućim razlozima zbog kojih podatak o Stepinčevoj naslovnoj crkvi u Rimu nikada nije objavljen. U svjetlu činjenice da naša pretraga u diplomatskom arhivu vatikanskog Državnog tajništva nije pronašla spise koji bi upućivali na to da je Vatikan pokušao djelovati proaktivno u cilju održavanja diplomatskih odnosa s Jugoslavijom, navedena se pretpostavka ne može potvrditi.

67 Archivio dell'Ufficio delle Celebrazioni Liturgiche del Sommo Pontefice (dalje u tekstu: ACP), ACP 0246, Concistori 1946-1954, istruzioni per una canonizzazione, fasc. 5. 
Slijedom svega iznesenog, vjerodostojnim se čini mogućnost da je neobjavljivanje Stepinčeve naslovne crkve ishod spleta okolnosti u kojima ulogu imaju najprije propust, a zatim i zaborav. Dapače, ovaj je autor uvjeren da ni Stepincu osobno nije bio poznat podatak o tome koja mu je naslovna crkva dodijeljena jer o tome do smrti nije nikada ni govorio ni ostavio neki zapis. No, uzevši sve u obzir, vrlo je vjerojatno da Stepinčeva naslovna crkva nije objavljena upravo zbog njegove nemogućnosti dolaska u Rim.

\section{EPILOG: OBILJEŽAVANJE RIMSKE NASLOVNE CRIKVE BL. ALOJZIJA STEPINCA}

Nakon otkrića dokumenta s podatkom o Stepinčevoj naslovnoj crkvi te rekonstrukciji slijeda događaja, kojim je poduprta pretpostavka da je riječ o vjerodostojnom podatku i dokumentu, Veleposlanstvo Republike Hrvatske pri Svetoj Stolici obavilo je pripremne radnje da se mramornom spomen-pločom, postavljenom na unutarnjem zidu kapele Schola Sancti Pauli unutar crkve San Paolo alla Regola na primjeren način komemorira činjenica da je njezin prvi kardinalski naslovnik trebao biti nadbiskup zagrebački kardinal bl. Alojzije Stepinac, što bi on i postao da mu je bilo moguće stići u Rim.

Provedene su odgovarajuće procedure. Obavijest i prijedlog upućeni su nadležnim vlastima u Hrvatskoj - Uredu predsjednika Republike Hrvatske, predsjedniku Vlade Republike Hrvatske, Ministarstvu vanjskih i europskih poslova te Ministarstvu kulture i medija. Nakon dobivanja potrebnih suglasnosti Vlade RH i MVEP-a sa situacijom je upoznato Državno tajništvo Svete Stolice i dobivena je suglasnost državnog tajnika Pietra Parolina ${ }^{68}$ i Hrvatske biskupske konferencije ${ }^{69}$, zatim Vikarijata za Grad Rim $^{70}$ te u konačnici i od rektora crkve ${ }^{71}$

68 Državni tajnik Svete Stolice kardinal Pietro Parolin saslušao je detaljno izvješće koje smo iznijeli na ručku koji je u njegovu čast prigodom posjeta Splitu 15. rujna 2020. u povodu biskupskog ređenja mons. Ante Jozića priredio predsjednik Vlade Republike Hrvatske Andrej Plenković i suglasio se s prijedlogom te je svoju preporuku odmah i uputio Vikarijatu Rimske biskupije.

69 Na ručku prisutan predsjednik HBK-a nadbiskup zadarski Želimir Puljić o ovom otkriću istoga dana izvijestio je biskupe okupljene na zasjedanju HBK-a 15. rujna 2020. u Splitu.

70 Generalni vikar Njegove Svetosti za Grad Rim kardinal Angelo de Donatis također je dobio potrebnu dokumentaciju, saslušao namjeru Veleposlanstva, uz dobivenu preporuku Državnog tajništva, te je proveo odgovarajući postupak.

71 Upravitelji crkve San Paolo alla Regola su već stoljećima oci franjevci trećega reda sv. Franje provincije Južne Italije sa sjedištem u Napulju, koji su pretragom svojih 
i njezina trenutačnog naslovljenika kardinala đakona Francesca Monterisija ${ }^{72}$. Završno, bilo je potrebno ishoditi i suglasnost civilnih vlasti u Rimu koje su nadležne za kulturnu baštinu grada.

Čitav postupak trajao je od početka rujna do kraja prosinca 2020. godine, za vatikanske pojmove doista rekordno kratkom vremenu.

O svemu objavljeni su članci u hrvatskim i stranim medijima, u kojima je opisano na koji način je razriješen ovaj višedesetljetni misterij. U prvom redu tu je katolički tjednik Glas Koncila ${ }^{73}$ i dnevni list Talijanske biskupske konferencije Avvenire ${ }^{74}$. Najvažnijim, pak, rezultatom smatramo činjenicu kako je mrežna stranica Catholic Hierarchy svoju biografsku notu o blaženom Stepincu dopunila informacijom o njegovoj kardinalskoj naslovnoj crkvi. ${ }^{75}$ Iako nije riječ o službenom glasilu Svete Stolice, ta mrežna stranica je svima u Vatikanu referentna te je redovito konzultiraju i u Državnom tajništvu i u Uredu za bogoslužna slavlja.

Veleposlanstvo Republike Hrvatske pri Svetoj Stolici u prosincu 2020. godine u kapelici sv. Pavla u crkvi San Paolo alla Regola postavilo je prigodnu spomen-ploču na latinskom jeziku, s natpisom ispod blaženikova kardinalskog grba:

arhiva također bili iznenađeni nepostojanjem bilo kakve najave da je njihova crkva bila dodijeljena bl. Alojziju, ali su s entuzijazmom prihvatili ovu inicijativu.

72 Kardinal Monterisi bio je prvi apostolski nuncij u Bosni i Hercegovini (1993. 1998.) te je vrlo dobro upoznat s kauzom bl. Alojzija Stepinca. Njemu je također, iako je trenutačni naslovnik crkve San Paolo alla Regola, ova činjenica bila potpuno nepoznata, ali joj se neizmjerno razveselio.

73 https://www.glas-koncila.hr/napokon-rijesen-povijesni-misterij-zatocenomu-stepincu-papa-dodijelio-crkvu-nad-celijom-sv-pavla-apostola/ (23. veljače 2021.).

74 https://www.avvenire.it/chiesa/pagine/stepinac-e-il-titolo-ritrovato (23. veljače 2021.).

75 http://www.catholic-hierarchy.org/bishop/bstepinac.html (23. veljače 2021.). 


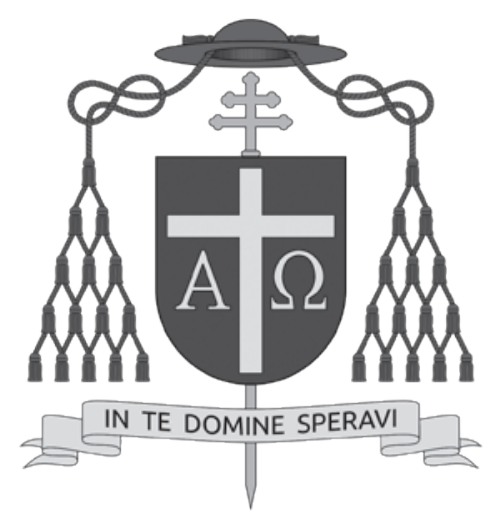

BEATO ALOISIO S.R.E. CARDINALI STEPINAC

HVIVS TEMPLI NACTO TITULUM

QVOD IN VINCVLIS DETENTVS NVMQVAM INTRAVIT

LX INTERVENIENTE DIE NATALI QVO IN CAELVM MIGRAVIT

LEGATIO REI PVBLIC Æ CROATI Æ APVD S. SEDEM POSVIT

\section{A.D. MMXX}

U hrvatskom prijevodu:

Blaženi Alojzije Svete rimske Crkve kardinal Stepinac dobio (je) naslov ove crkve u koju, zbog zatočeništva, nikada nije ušao; u povodu šezdesete obljetnice njegova preseljenja u nebo postavi Veleposlanstvo RH pri Svetoj Stolici, godine Gospodnje 2020. 


\section{LITERATURA}

Avvenire, https://www.avvenire.it/chiesa/pagine/stepinac-e-il-titolo-ritrovato (23. veljače 2021.).

Batelja, Juraj, Blaženi Alojzije Stepinac-svjedok Evanđelja ljubavi, Knjiga 1: Životopis, Postulatura blaženoga Alojzija Stepinca, Zagreb, 2010.

Batelja, Juraj, Komunistički progon i mučeništvo blaženoga Alojzija Stepinca, Postulatura blaženoga Alojzija Stepinca, Zagreb, 2017.

Benigar, o. Aleksa, Alojzije Stepinac, hrvatski kardinal, II. popravljeno i prošireno izdanje, Glas Koncila i Hrvatska franjevačka provincija sv. Ćirila i Metoda, Zagreb, 1993.

Bešker, Inoslav, Iza vatikanskih zidina, EPH, Zagreb, 2013.

Boudinhon, Auguste, Minor Orders, u: The Catholic Encyclopedia, vol. 10, Robert Appleton Company, New York, 1911.

Catholic Heraldry, http://www.catholic-hierarchy.org/bishop/bstepinac.html (23. veljače 2021.).

Enciclopedia cattolica, III (Bra - Col), Ente per l'Enciclopedia cattolica per il libro cattolico, Sansoni, Firenze, 1949.

Gavranović, Zvonimir, In Search of Cardinal Stepinac - A Complete Biography, Kršćanska sadašnjost, Zagreb, 2014.

Parisi, Giovanni, La prima dimora di San Paolo a Roma, Casa Editrice Carteggio, Torino, 1959.

Glas koncila, https://www.glas-koncila.hr/napokon-rijesen-povijesni-misterij-zatocenomu-stepincu-papa-dodijelio-crkvu-nad-celijom-sv-pavla-apostola/ (23. veljače 2021.).

Milanski edikt, Hrvatska enciklopedija, mrežno izdanje, Leksikografski zavod "Miroslav Krleža", 2020., dostupno na: http://www.enciklopedija.hr/Natuknica.aspx?ID=40820 (16. prosinca 2020.)

Pierantozzi, Gaudenzio, Teodolfo Mertel - L'ultimo Cardinale laico, Edizioni Cantagalli, Siena, 2016.

Vraneković, Josip, Dnevnik - Život u Krašiću zasužnjenog nadbiskupa i kardinala Alojzija Stepinca (5. XII. 1951. - 10. II. 1960.), Postulatura blaženoga Alojzija Stepinca, Zagreb, 2011. 
Summary

\section{Neven Pelicarić*}

\section{CANON LAW AND HISTORICAL ASPECTS OF THE CREATION OF ZAGREB ARCHBISHOP ALOYSIUS STEPINAC AS CARDINAL OF THE HOLY ROMAN CHURCH The Discovery of His Titular Church in Rome}

Following the decision of Pope Francis to open the Archives of the Pontificate of pope Pius XII (Pacelli) in March 2020, an opportunity arose to endeavor to solve the mystery of the unknown titular church that was to be assigned to the Archbishop and Metropolitan of Zagreb Blessed Aloysius Card. Stepinac in 1953. Canon Law explicitly states that the Roman Pontiff assigns each of the cardinals his own title or diaconia in Rome. That is a prerequisite for them to get incardinated into the clergy of Rome, thus gaining active electoral power in electing a future Pope, once gathered in a Conclave.

Notwithstanding the numerous studies and biographies that went into the depths of the life of Blessed Aloysius, and were crowned with the canonical process of his beatificationthis particular aspect of his creation as a cardinal was never researched. The author was convinced that he must have been assigned a titular church in its time, but it remained unknown not only to the general public but to researches as well.

An easier and unimpeded access to the various Archives was enjoyed by the author even during the pandemic restrictions, due to the fact that at the time of research he was serving as Ambassador of his country to the Holy See. He was allowed to consult numerous Archives, including but not limited to the Apostolic Archive, the Archives of the Sacred College of Cardinals, the Congregation for Bishops, the Congregation for Doctrine of Faith, and the Archives of both Sections of the Secretariat of State - all initially to no avail.

However, in the Archive of the Office for the Liturgical Celebrations of the Supreme Pontiff, persistent research produced heretofore unknown, unsigned and undated document pertaining to the final preparations for the Consistory of 1953. The document indicated that, during said Consistory, held on 12 January 1953, Pope Pius XII indeed assigned newly created cardinal Aloysius Stepinac his titular church - SANCTI PAULI IN ARENULA (San Paolo alla Regola).

A procedure to verify the truthfulness and authenticity of this document has been developed. The scientific method also suggested beyond reasonable doubt that this titular church assignment complied with true and explicit wishes of Pius XII.

* Neven Pelicarić, LL. M., Foreign and European Policy Advisor to the President of the Republic, Pantovčak 241, 10000 Zagreb; neven.pelicaric@predsjednik.hr;

ORCID ID: orcid.org/0000-0003-3032-5300 
It is a well-established and commonly known fact that all newly created cardinals have to be assigned a titular church in Rome, and that the Vatican administration has carefully and consistently recorded these assignments for centuries. Explanations and potential reasons are therefore also provided as to why the question of the existence and identification of Stepinac's titular church has not previously been researched.

Key words: Aloysius Stepinac, cardinal, consistory, titular church 